\title{
Experiences in the evaluation of carcass value of live pigs by ultrasonic photography
}

\author{
Mikko Varo, Marjatta Perälä, Matti Ojala and Hannu Varo \\ University of Helsinki, Department of Animal Breeding
}

\begin{abstract}
In the present study it was found that the mean cross-sectional lean area of three ultrasonic photographs has a closer correlation than any one of the three individual areas to the cross-sectional lean area measured from the carcass. The correlation of this mean value with the lean + bone amount of the most valuable part of the halfcarcass approached that of the cross-sectional area of the lean measured from the carcass. The correlation of the ultrasonic area measurements with the carcass amounts of fat and lean + bone and with the fat-lean ratio calculated from these was closer than that of the ultrasonic thickness measurements. The fat-lean ratio calculated from the areas was also slightly better correlated to carcass quality than was the ratio calculated from the thickness measurements. In other respects the fat thickness measurements appeared to be better than area measurement. Although the measurement of lean correlated to the carcassa value of the animal more poorly than the fat measurements, the highest correlations were nevertheless obtained by the combined use of the fat and lean measurements.
\end{abstract}

\section{Introduction}

The Department of Animal Breeding of the University of Helsinki has, with the financial support of the Finnish National Research Council for Agriculture and Forestry, procured a Scanogram ultrasonic photographic device developed in the United States by Professor Stouffer (STOuffer 1965) with which pictures of cross-sectional areas of fat and lean can be obtained in live animals. This instrument was used for photographic measurements of litters reared for progeny testing of boars done in form of Danish at the Pig Husbandry Experiment Station in Hyvinkää in 1970 and 1971. Quite satisfactory results were obtained already at the training stage during the first year. The results here presented are based on the measurements made in 1971 .

\section{Material and methods}

The material studied comprised ten test litters of Yorkshire and ten of Finnish Landrace, totalling $\mathbf{8 0}$ animals. One week prior to slaughter ultrasonic photographs were taken at three sites: the middle picture B was obtained behind the last thoracic vertebra, picture $A 10 \mathrm{~cm}$ anterior to $\mathrm{B}$, and $\mathrm{C}$ the 
same distance posterior to B. From these cross-sectional pictures of the back the thickness and area of lean and the thickness and area of fat were measured and the fat-lean ratio was calculated. Since, in addition to the ultrasonic measurements, the normal test results and carcass measurements were also obtained for these animals, it was possible to compare the carcass values estimated from the live animals with the actual carcass values obtained on dissection.

The comparisons between the ultrasonic photography results and the carcass measurements were made by means of correlation coefficients calculated individually within breeds and within sexes and by test litters within breeds. The combining of the results of the small material in this manner was considered meaningful because the breeds did not differ significantly, as will be seen below. This simplified the treatment of the subject. The sexes differed significantly with respect to several characteristics. Such differences could have caused errors in the correlation coefficients computed on individual basis had they not been calculated within sexes.

\section{Results}

The mean values and standard deviations, the coefficients of heritability of the ultrasonic measurements, and the significances of differences between the test litters and the sexes are presented in Table 1. A statistically significant difference between the breeds was found only in the thickness of the lean at site A. It is a noteworthy finding that, with the two exceptions of lean thickness and area at $\mathrm{A}$, the standard deviations of values were greater in the Yorkshire than in the Finnish Landrace. The differences were even quite significant with respect to fat and the fat-lean ratio. The coefficients of heritability were estimated from variations between the test litters, since with one or two exceptions each boar had only one litter in the test. Although the numerical readings of heritability coefficients should be accepted with some reservation because of the small material, it is possible on the basis of their relative magnitudes to compare the reliability of the different measurements. Investigators have generally found a greater heritability of thickness of fat than of thickness of lean. The coefficient of heritability of the fat lean ratio, again, approaches that of fat. Certain coefficients of heritability of ultrasonic measurements obtained in large pig materials are cited below:

$\begin{array}{ccccl}\begin{array}{c}\text { Fat } \\ \text { thickness }\end{array} & \begin{array}{c}\text { Lean } \\ \text { thickness }\end{array} & \begin{array}{c}\text { Fat-lean } \\ \text { ratio }\end{array} & \mathrm{n} & \text { Author } \\ 0.59 & 0.35 & 0.48 & 1096 & \text { GLODEK (1964) } \\ 0.25 & 0.24 & 0.26 & 1673 & \text { RITTLER (1966) } \\ 0.40 & 0.10 & 0.40 & 7353 & \text { LAUPRECHT et al. (1967) } \\ 0.34-0.38 & 0.26-0.34 & 0.33-0.38 & 1332 & \text { RITTLER (1967) } \\ 0.33-0.35 & 0.30-0.40 & 0.37-0.43 & 3437 & \end{array}$

In the light of the correlations between ultrasonic measures presented in Table 2 it appears that the reliability of measurements was greater for the Yorkshire breed than for the Landrace. This may have been due to the difference in standard deviations of values of the two breeds in the present material. 
Table 1. Means, standard deviations and heritability coefficients of ultrasonic measurements and significance of differences between test litters (L) and sexes (S).

\begin{tabular}{|c|c|c|c|c|c|c|c|c|c|c|}
\hline \multirow{3}{*}{ Characteristic } & & \multicolumn{3}{|c|}{ Landrace } & \multicolumn{3}{|c|}{ Yorkshire } & \multirow{2}{*}{\multicolumn{3}{|c|}{$\begin{array}{c}\text { Total } \\
\text { material }\end{array}$}} \\
\hline & & \multirow{2}{*}{$\frac{\mathrm{C}}{\mathrm{x}}$} & \multirow{2}{*}{$\frac{\mathrm{G}}{\overline{\mathrm{x}}}$} & \multirow{2}{*}{$\begin{array}{c}\mathrm{C}+\mathrm{G} \\
\sigma\end{array}$} & \multirow{2}{*}{$\frac{C}{\bar{x}}$} & \multirow{2}{*}{$\frac{G}{x}$} & \multirow{2}{*}{$\begin{array}{c}\mathrm{C}+\mathrm{G} \\
\quad \sigma\end{array}$} & & & \\
\hline & & & & & & & & $h^{2}$ & L & S \\
\hline \multirow[t]{4}{*}{ Fat thickness, mm } & A & 21 & 19 & 2.65 & 22 & 21 & 4.12 & 0.43 & & $*$ \\
\hline & B & 22 & 20 & 2.45 & 23 & 22 & 3.74 & 0.54 & * & \\
\hline & C & 25 & 23 & 3.32 & 25 & 24 & 4.58 & 0.86 & $* *$ & \\
\hline & $\bar{x}$ & 22 & 20 & 2.45 & 23 & 22 & 4.00 & 0.66 & $*$ & * \\
\hline \multirow[t]{4}{*}{ Lean thickness, $\mathrm{mm}$} & A & 38 & 39 & 3.16 & 36 & 37 & 2.45 & 0.48 & $*$ & \\
\hline & B & 38 & 39 & 2.45 & 37 & 38 & 2.65 & 0.55 & $*$ & \\
\hline & C & 38 & 40 & 3.46 & 39 & 40 & 3.87 & 0.53 & & \\
\hline & $\bar{x}$ & 38 & 39 & 2,65 & 37 & 38 & 2.65 & 0.83 & $* *$ & * \\
\hline \multirow{4}{*}{$\begin{array}{l}\text { Fat-lean ratio } \\
\text { of thicknesses }\end{array}$} & A & 0.55 & 0.48 & 0.10 & 0.63 & 0.57 & 0.14 & 0.36 & * & $*$ \\
\hline & B & 0.58 & 0.51 & 0.08 & 0.63 & 0.58 & 0.12 & 0.55 & * & $*$ \\
\hline & C & 0.64 & 0.58 & 0.11 & 0.66 & 0.62 & 0.17 & 0.89 & $* *$ & \\
\hline & $\overline{\mathrm{x}}$ & 0.59 & 0.53 & 0.09 & 0.64 & 0.59 & 0.14 & 0.62 & $*$ & * \\
\hline \multirow[t]{4}{*}{ Fat area, $\mathrm{cm}^{2}$} & A & 26.5 & 25.2 & 2.82 & 29.1 & 27.1 & 4.86 & 0.37 & & \\
\hline & B & 29.7 & 27.5 & 2.97 & 30.9 & 29.8 & 5.30 & 0.69 & $*$ & \\
\hline & C & 34.4 & 31.9 & 3.57 & 34.5 & 33.9 & 5.67 & 1.17 & $* * *$ & * \\
\hline & $\bar{x}$ & 30.2 & 28.2 & 2.72 & 31.5 & 30.3 & 4.88 & 0.82 & $* *$ & \\
\hline \multirow[t]{4}{*}{ Lean area, $\mathrm{cm}^{2}$} & A & 24.4 & 26.6 & 2.76 & 24.8 & 26.5 & 2.42 & 0.11 & & $* *$ \\
\hline & B & 27.3 & 28.3 & 1.97 & 27.3 & 29.1 & 2.24 & 0.04 & & ** \\
\hline & $\mathrm{C}$ & 28.6 & 29.7 & 2.19 & 28.6 & 30.3 & 2.83 & 0.31 & & * \\
\hline & $\bar{x}$ & 26.8 & 28.2 & 1.85 & 26.9 & 28.6 & 2.02 & 0.25 & & *** \\
\hline \multirow{4}{*}{$\begin{array}{l}\text { Fat-lean ratio } \\
\text { of areas }\end{array}$} & A & 1.10 & 0.95 & 0.17 & 1.20 & 1.04 & 0.26 & 0.45 & * & ** \\
\hline & B & 1.10 & 0.98 & 0.14 & 1.14 & 1.03 & 0.22 & 0.76 & $* *$ & $* *$ \\
\hline & $\mathrm{C}$ & 1.21 & 1.08 & 0.17 & 1.22 & 1.14 & 0.27 & 1.05 & $* * *$ & $* *$ \\
\hline & $\bar{x}$ & 1.14 & 1.00 & 0.15 & 1.19 & 1.07 & 0.24 & 0.79 & ** & $* *$ \\
\hline $\begin{array}{l}\mathrm{C}=\text { Castrates } \\
\mathrm{G}=\text { Gilts } \\
\mathrm{A}, \mathrm{B}, \mathrm{C}=\text { Sites o } \\
\overline{\mathrm{x}}=\text { Average } \mathrm{A},\end{array}$ & $\mathrm{B}$, & ures & ats & & & & & & & \\
\hline
\end{tabular}

The correlations demonstrate further the importance of measuring the fat and the lean separately because the connection between them is relatively small. Similar correlations between the thickness of fat and lean have been calculated by the following workers:

\begin{tabular}{cccl} 
Phenotypic & Cenetic & $\mathrm{n}$ & \multicolumn{1}{c}{ Author } \\
-0.27 & -0.43 & 1673 & RitTLER (1966) \\
-0.18 & -0.45 & 7353 & LAUPRECHT et al. (1967) \\
-0.16 & $-0.04--0.10$ & 3437 & RitTLER (1967) \\
$-0.02--0.24$ & - & 412 & LANGLET et al. (1968)
\end{tabular}


Table 2. Correlation coefficients between dimensions measured from ultrasonic photographs. Calculations are based on the mean values of three photographs (ABC).

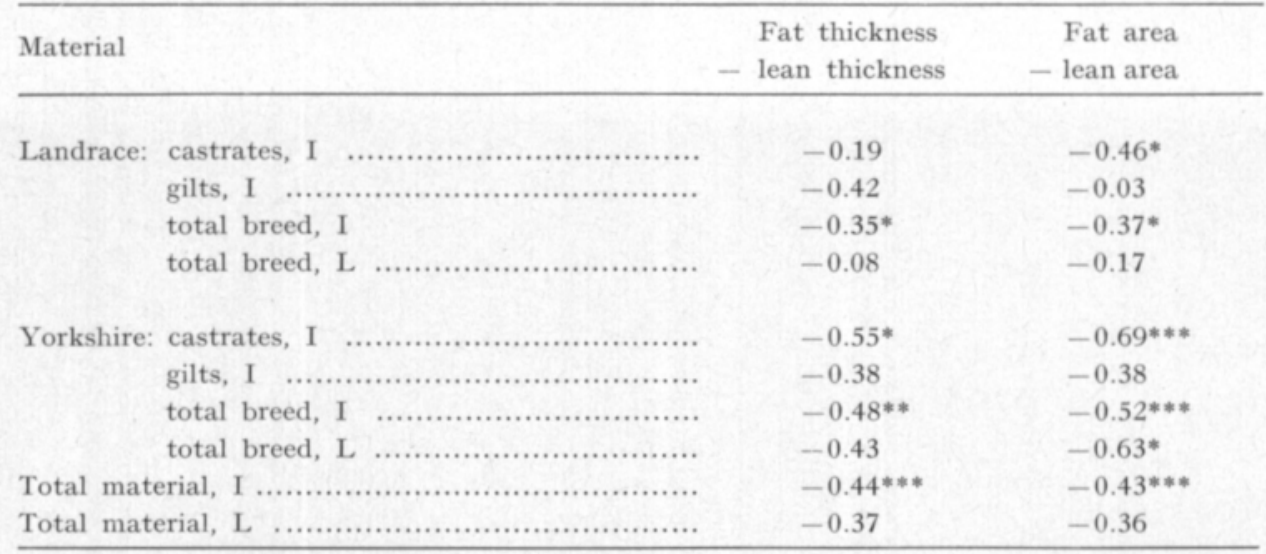

$I=$ calculated from individual values

$\mathrm{L}=$ calculated from test litter means

Table 3 shows the properties that are the most important and in the present connection the mos interesting characteristics obtained by carcass evaluation. Lean + bone is the combined weight of lean and bone in the most valuable part of the left half of the carcass. Fat is the corresponding weight of fat, and the fat-lean ratio is the ratio between the two. The most valuable part of half carcass consists of ham, loin, back, foreback and choulder. The area of m.l.dorsi was measured from the carcass broken behind the last rib, i.e. at the site of ultrasonic picture B. The side points are based on sensory evaluation. For the posterior points (II) the amounts of fat and lean were estimated from the cross-section surface of the carcass broken behind the last rib. The points $(\mathbf{1}-\mathbf{5})$ increase with increasing relative amount of lean. The middle points (I) are evaluated similarly from about the middle of the rib piece. The remarks

Table 3. Means, standard deviations and heritability coefficients of some characteristics determined by carcass evaluation, and significance of differences between litters (L) and sexes (S).

\begin{tabular}{|c|c|c|c|c|c|c|c|c|c|}
\hline \multirow{3}{*}{ Characteristic } & \multicolumn{3}{|c|}{ Landrace } & \multicolumn{3}{|c|}{ Yorkshire } & \multirow{2}{*}{\multicolumn{3}{|c|}{$\begin{array}{c}\text { Total } \\
\text { material }\end{array}$}} \\
\hline & \multirow{2}{*}{$\frac{\mathrm{C}}{\mathrm{x}}$} & \multirow{2}{*}{$\frac{G}{x}$} & \multirow{2}{*}{$\begin{array}{c}\mathrm{C}+\mathrm{G} \\
\sigma\end{array}$} & \multirow{2}{*}{$\frac{c}{x}$} & \multirow{2}{*}{$\frac{\mathrm{G}}{\mathrm{x}}$} & \multirow{2}{*}{$\begin{array}{c}\mathrm{C}+\mathrm{G} \\
\sigma\end{array}$} & & & \\
\hline & & & & & & & $\mathrm{h}^{2}$ & $\mathbf{L}$ & $\mathbf{S}$ \\
\hline Carcass weight, $\mathrm{kg}$............. & 65.3 & 65.1 & 2.16 & 65.4 & 65.5 & 2.30 & & & \\
\hline Lean + bone, $\mathrm{kg} \quad \ldots \ldots \ldots \ldots \ldots$ & 14.33 & 14.65 & 0.89 & 14.49 & 14.12 & 0.94 & 0.90 & ** & * \\
\hline 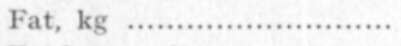 & 4.93 & 4.49 & 0.63 & 5.12 & 4.93 & 0.78 & 0.33 & & \\
\hline Fat lean ratio $. . . \ldots \ldots \ldots \ldots \ldots . . . . . . .$. & 0.35 & 0.31 & 0.06 & 0.37 & 0.34 & 0.07 & 0.61 & $*$ & * \\
\hline M.1. dorsi area, $\mathrm{cm}^{2}$.......... & 29.3 & 31.5 & 3.22 & 27.2 & 30.6 & 3.69 & 0.63 & $* *$ & $* * *$ \\
\hline Back fat thickenss, mm: ... & 28.9 & 27.3 & 3.83 & 29.9 & 29.0 & 4.82 & 0.67 & $* *$ & \\
\hline Side fat thickness, $\mathrm{mm}$....... & 25 & 22 & 3.87 & 25 & 23 & 5.57 & 0.86 & $*$ & * \\
\hline Side points I (middle) $\ldots . .$. & 2.6 & 2.9 & 0.44 & 2.6 & 3.1 & 0.66 & 0.64 & $*$ & ** \\
\hline Side points II (posterior) $\ldots$ & 3.2 & 3.2 & 0.46 & 3.1 & 3.5 & 0.64 & 0.65 & $*$ & ** \\
\hline
\end{tabular}


Table 4. Correlation coefficients between some carcass evaluation characterisics.

\begin{tabular}{|c|c|c|c|c|c|c|c|}
\hline 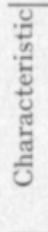 & 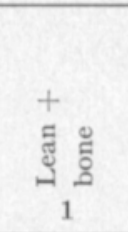 & $\frac{\vec{W}}{2}$ & 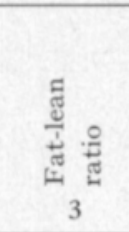 & 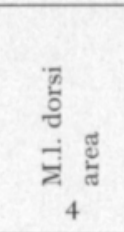 & 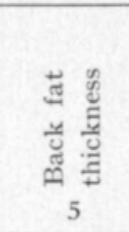 & 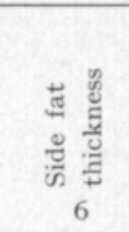 & 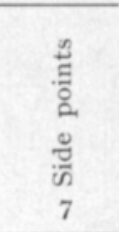 \\
\hline 1 & - & $-.52 * * *$ & $-.74 * * *$ & $.72 * * *$ & $-.41^{* * *}$ & $-.59 * * *$ & $.50^{* * *}$ \\
\hline 2 & $-.67^{* *}$ & - & $.96 * * *$ & $-.59 * * *$ & $.67 * * *$ & $.80^{* * *}$ & $-.48 * * *$ \\
\hline 3 & $-.83^{* * *}$ & $.97^{* * * *}$ & - & $-.70^{* * *}$ & $.66^{* * * *}$ & $.84 * * *$ & $-.54 * * *$ \\
\hline 4 & $.72^{* * * *}$ & $-.60^{* *}$ & $-.70^{* * *}$ & - & $-.39 * * *$ & $-.60^{* * *}$ & $.53^{* * *}$ \\
\hline 5 & $-.48^{*}$ & $.80^{* * *}$ & $.75^{* * * *}$ & .35 & - & $.71^{* * * *}$ & $-.47^{* * *}$ \\
\hline 6 & $-.62 * *$ & $.82^{* * *}$ & $.82^{* * *}$ & $-.57^{* *}$ & $.79 * * *$ & - & $-.58 * * *$ \\
\hline 7 & $.58^{* *}$ & $-.51^{*}$ & $-.56^{* *}$ & $.60^{* *}$ & $-.50 *$ & $-.58 * *$ & - \\
\hline
\end{tabular}

The correlations calculated from individual values are presented in the uppert par, and these calculated from test litter means in the lower part of table.

in Table 1 on standard deviations and coefficients of heritability are valid also here.

Table 4 presents the correlations between the characteristics included in carcass evaluation. The coefficients in the upper half of the matrix were calculated from the individual values and those in the lower part from the test litter means. With a few exceptions the latter coefficients are higher than those individually calculated.

The correlation coefficients presented in Table $\mathbf{5}$ show that the connection between the individual measurements (A, B, C) and the area of ml.dorsi actually measured on the carcass was usually poorer than the correlation between the mean values $\left(\frac{\mathrm{A}+\mathrm{B}+\mathrm{C}}{3}\right)$ of the ultrasonic measures and the lean area.

Table 5. Correlation coefficients between ultrasonic and carcass measurements of lean area.

\begin{tabular}{|c|c|c|c|c|}
\hline Material & A & B & $\mathrm{C}$ & $\overline{\mathbf{x}}$ \\
\hline Landrace: castrates, I $\ldots \ldots \ldots \ldots \ldots \ldots . . . . . .$. & $0.60^{* *}$ & $0.58 * *$ & $0.68 * * *$ & $0.80^{* * *}$ \\
\hline 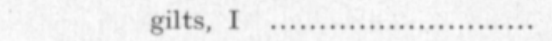 & $0.66^{* *}$ & $0.51^{*}$ & $0.57 * *$ & $0.76 * * *$ \\
\hline total breed, I .................. & $0.68 * * *$ & $0.58 * * *$ & $0.66 * * *$ & $0.81 * * *$ \\
\hline 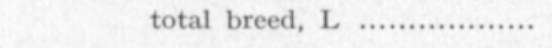 & $0.77 * *$ & 0.52 & $0.70^{*}$ & $0.88 * * *$ \\
\hline Yorkshire: castrates, I .... & $0.65 * *$ & 0.06 & $0.69 * * *$ & $0.64 * *$ \\
\hline 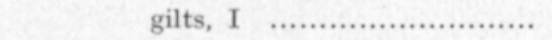 & 017 & $0.83 * * *$ & $0.69 * * *$ & $0.73 * * *$ \\
\hline total breed, I ................... & $0.50 * * *$ & $0.59 * * *$ & $0.72 * * *$ & $0.75^{* * *}$ \\
\hline total breed, $\mathrm{L}$.................. & 0.56 & 0.46 & $0.72^{*}$ & $0.69 *$ \\
\hline Total material, I .. & $0.57 * * *$ & $0.55 * * *$ & $0.66 * * *$ & $0.74 * * *$ \\
\hline Total material, $\mathbf{L}$......................... & $0.59 * *$ & 0.38 & $0.63 * *$ & $0.67 * *$ \\
\hline
\end{tabular}

$I=$ calculated from individual values

$\mathbf{L}=$ calculated from test litter means 
Table 6. Correlation coefficients between ultrasonic and carcass measurements of lean area and amount of lean + bone in half-carcass.

\begin{tabular}{|c|c|c|c|c|c|c|}
\hline \multirow{2}{*}{ Material } & & \multicolumn{4}{|c|}{ Area measured from ultrasonic photograph } & \multirow{2}{*}{$\begin{array}{l}\text { Area measured } \\
\text { from carcass }\end{array}$} \\
\hline & & A & B & $\mathrm{C}$ & $\overline{\mathbf{x}}$ & \\
\hline \multirow[t]{4}{*}{ Landrace: } & castrates, I ........ & $0.55^{*}$ & $0.64 * *$ & $0.67^{* *}$ & $0.79 * * *$ & $0.77 * * *$ \\
\hline & gilts, I ............. & $0.56 * *$ & 0.06 & 0.23 & 0.38 & $0.69 * * *$ \\
\hline & total beed, I ........ & $0.57 * * *$ & $0.37 *$ & $0.50 * * *$ & $0.62 * * *$ & $0.73^{* * *}$ \\
\hline & total beed, $\mathrm{L}$....... & $0.67^{*}$ & 0.09 & 0.43 & 0.57 & $0.63^{*}$ \\
\hline \multirow{4}{*}{\multicolumn{2}{|c|}{$\begin{array}{r}\text { Yorkshire: } \text { castrates, I ......... } \\
\text { gilts, I } \ldots \ldots \ldots \ldots \ldots \\
\text { total breed, I } \ldots \ldots . \\
\text { total breed, L } \ldots \ldots\end{array}$}} & $0.61 * *$ & 0.36 & $0.64 * *$ & $0.68 * * *$ & $0.77^{* * *}$ \\
\hline & & 0.35 & 0.26 & 0.37 & 0.42 & $0.52 *$ \\
\hline & & $0.55^{* *}$ & $0.35^{*}$ & $0.55^{* * *}$ & $0.61^{* * *}$ & $0.69^{* * *}$ \\
\hline & & 0.58 & 0.41 & $0.65^{*}$ & $0.65^{*}$ & $0.74^{*}$ \\
\hline \multirow{2}{*}{\multicolumn{2}{|c|}{$\begin{array}{l}\text { Total material, I ................ } \\
\text { Total material, L } \ldots \ldots \ldots \ldots \ldots\end{array}$}} & $0.54 * * *$ & $0.33^{* *}$ & $0.51 * * *$ & $0.58^{* * *}$ & $0.72 * * *$ \\
\hline & & $0.55^{*}$ & 0.22 & $0.51^{*}$ & $0.54^{*}$ & $0.72^{* * *}$ \\
\hline
\end{tabular}

$\mathrm{I}=$ calculated from individual values

$\mathbf{L}=$ calculated from test litter means

The same is true also of the correlations between the ultrasonic measurements and the carcass lean + bone amounts, as is seen in Table 6. Reliability, however, is not notably increased by using the mean of more than three pictures (ANDERSON \& WAHLstrom 1969 and LAUprecht et al. 1965). The coefficients in Table 5 agree well with values reported in the literature, e.g. 0.74 (PRICE et al. 1960); 0.70 (Stouffer et al. 1960); 0.66-0.85 (BlendL 1969); 0.68 (ANdersen et al. 1970); 0.57 (Horst 1971); 0.55-0.70 (Busk \& Pedersen 1972). From Table 6 it can be noted further that the mean of ultrasonically obtained values very satisfactorily measures the amount of carcass lean + bone as compared to measurement of the m.l.doresi area in the carcass.

In pig breeding aiming at improvement of the carcass value the main objectives are an increased proportion of lean and a decreased proportion of fat in the carcass, or in terms of the two goals combined: changing of the fat-lean ratio in a direction more favourable for lean meat production. The carcass values estimated from live animals are therefore compared below with the amounts of fat and of lean + bone measured from the carcass and with their ratio. These correlation coefficients are presented in Table 7: The coefficients were calculated on the base of the means of the three pictures $(A, B, C)$. It will be noted from the figures in this table that fat thickness is on the average better indicator of the carcass value of the slaughtered animal than fat area, whereas the opposite is the case with lean. The betterness of lean area reflected in the fat-lean ratio, which on the average estimates the quality of the carcass slightly better when calculated from the area dimensions. When the calculations were based on the test litter means the lean measurements obtained from live animals of landrace were clearly better than the fat measurements as indicators of the true amount of carcass lean + bone. The situation is not as clear with respect to the amount of fat and the fat-lean 


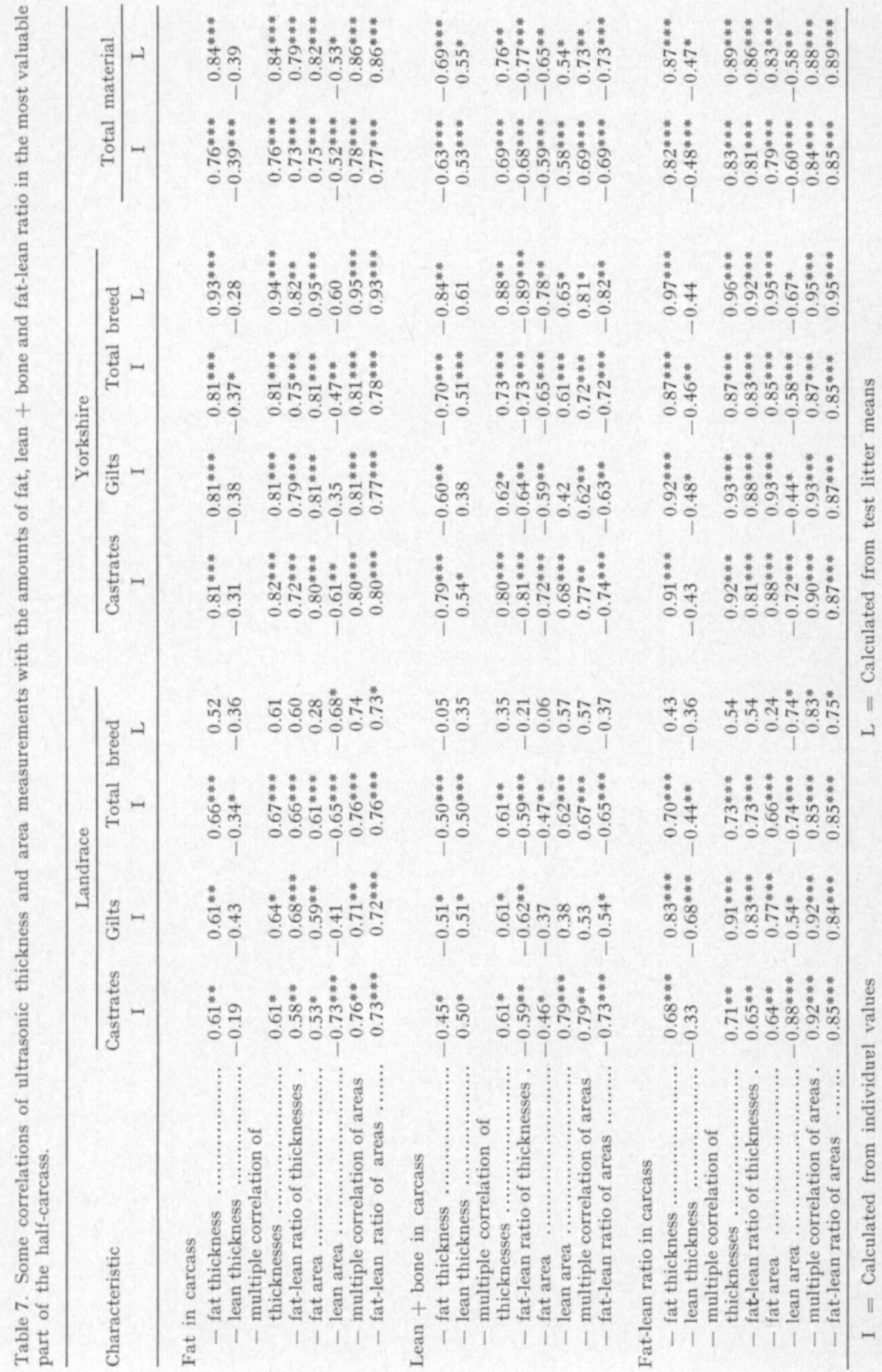


ratio in carcass. In Yorkshires the fat measurements gave in all cases higher correlations than the lean measurements. Although the measurements of lean evaluate the slaughter value less satisfac torily than the measurements of fat, it will be seen from the table that the best estimate on carcass value is obtained when the fat and lean measurements are used in combination.

The correlation of the ultrasonic values of fat and lean combined, i.e. the multiple correlation, with the actual carcass value is generally higher than the simple correlation calculated from their ratio. In calculating the fat-lean ratio the effect of the measurements on the carcass value were combined without weighting. In multiple correlation, on the other hand, they have been weighted with the weight coefficients leading to maximum correlation.

Generelly it has been found that fat measurements obtained ultrasonically evaluate the amounts of fat and lean + bone with the same reliability as do fat measurements from the carcass (Appendices A,B and C). In also the evaluation of the carcass fat-lean ratio the ultrasonic fat measurements are equal to the carcass fat measurements. On the other hand, the results of ultrasonic lean measurements evaluate the carcass value less well than the respective measurements made from the carcass. The measurement of lean by means of ultrasonic is also less reliable in general than that of fat.

Fom Table 8 will be seen in which extent the ultrasonic measurements give an estimate of the carcass value or general breeding value. As an estimate of the percentage of lean in the carcass the ultrasonic measurements proved in the present tests to be of quite equal value as in the studies of BECH ANDERSEn et al. (1970) and Busk \& Pedersen (1972). The figures presented in the table, which are correlation coefficients calculated by test litters within breeds, show that the fat-lean ratio best describes the various characteristics of carcass value and also the feed efficiency and the index of test results. This means that the information obtained from the fat concerning not only the carcass value but also other breeding values is supplemented and improved by the information obtained from the lean. Nevertheless, the figures indicating growth, one of which is calculated as the average daily growth and the other as age at slaughter, are indicated by the fat-lean ratio no better than by fat alone. On comparison of the determining measures in the table it can be said that the lean measure emphasizes directly the main objective of breeding, i.e. meat content of the carcass, and the test result index, which latter additionally takes growth into consideration. Evaluation of the live animal solely on the basis of fat reduces most effectively the amount of fat and improves growth and feed efficiency, but it does not focus sufficient attention on increasing the amount of lean. The best result is evidently obtained also here by using the fat and the lean measurements together.

Table 9 presents the correlation matrix of varoiusly compiled indices and feed consumption. The figures are within-breed correlations calculated by test litters. Feed consumption has been included in the comparisons because it is not included in the indices although it is an important factor in working towards the maximum economic endresult. It is therefore interesting to know how selection for breeding based on these indices takes feed consumption into consideration. 
Table 8. Means of ultrasonic measurements of live animals as estimates of certain litter test results.

\begin{tabular}{|c|c|c|c|c|c|c|}
\hline \multirow{3}{*}{ Dependent variables } & \multicolumn{6}{|c|}{ Independent variables } \\
\hline & \multicolumn{2}{|c|}{ Fat area } & \multicolumn{2}{|c|}{ Lean area } & \multicolumn{2}{|c|}{ Fat-lean ratio } \\
\hline & $\overline{\mathrm{r}}$ & $\overline{\mathrm{r}^{2}}$ & $\overline{\mathrm{r}}$ & $\overline{\mathrm{r}^{2}}$ & $\mathbf{r}$ & $\mathrm{r}^{2}$ \\
\hline Percent lean............. & $-0.51 *$ & 0.26 & $0.73^{* * *}$ & 0.54 & $-0.77 * * *$ & 0.59 \\
\hline Lean, gm/day ............... & $-0.60^{* *}$ & 0.36 & $0.48^{*}$ & 0.23 & $-0.73 * * *$ & 0.54 \\
\hline Fat thickness $\overline{\mathbf{x}} \quad \ldots \ldots \ldots \ldots$ & $0.75 * * *$ & 0.57 & $-0.44^{*}$ & 0.19 & $0.81 * * *$ & 0.66 \\
\hline Slaughter loss ................. & -0.29 & 0.09 & -0.10 & 0.01 & -0.17 & 0.03 \\
\hline Growth, gm/day ............. & $-0.68 * * *$ & 0.46 & 0.29 & 0.09 & $-0.68 * * *$ & 0.46 \\
\hline Age at $88 \mathrm{~kg} \quad \ldots \ldots \ldots \ldots \ldots$ & $0.56 * *$ & 0.31 & -0.22 & 0.05 & $0.56 * *$ & 0.31 \\
\hline $\begin{array}{l}\text { Feed efficiency, feed } \\
\text { units } / \mathrm{kg} \quad \ldots \ldots \ldots \ldots \ldots \ldots\end{array}$ & $0.66^{* *}$ & 0.44 & -0.39 & 0.16 & $0.72^{* * *}$ & 0.52 \\
\hline 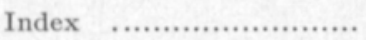 & $-0.62 * *$ & 0.38 & $0.59 * *$ & 0.35 & $0.80^{* * *}$ & 0.65 \\
\hline
\end{tabular}

Table 9. Correlation matrix of feed efficiency and indices compiled in various ways.

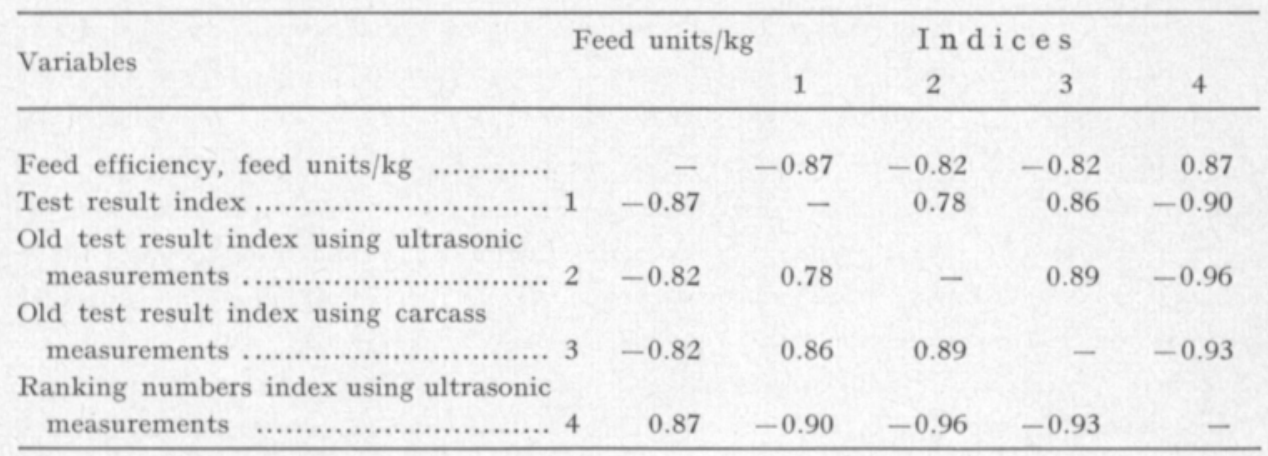

All correlations are highly significant

The indices are:

1. The test result index currently in use, based on the carcass dissection and calculated from the following formula:

$I=\frac{\text { Lean }+ \text { bone }(\mathrm{kg}) \cdot \text { Lean }+ \text { bone }(\%)}{\text { Days in experiment station }+ \text { age on arrival at station : } 2}$

2 and 3. The old test result index calculated as the sum of standard values of the included characteristics weighted with the heritability coefficient and with the economic weight factor. The characteristics were thinness of fat, crossectional area of m.l. dorsi, length of side, daily weight gain, and points for ham. Index 3 was calculated from carcass measurements of the characteristics, and index 2, except the ham points, was calculated on the base of the 
ultrasonic photographs of fat and lean areas. It was also necessary to use length of carcass because the length of live animals was not mesured.

4. The ranking numbers index used in the progeny testing of boars in field conditions in the district of Salpausselkä Artificial Insemination Society (VARO 1967) is based on the characteristics used in index 2. To compose the index the ranking numbers of the test litters with respect to each characteristic added up without weighting.

Table 9 shows that the correlations between all the indices are very close, as also is their correlations with the feed consumption. The superiority of the ranking numbers index over the old test result index can probably be accounted for by the fact that the economic weight factors, which lower the heritability, are not used in its calculation. The close correlation between the various indices and feed consumption indicates that the present mode of selection favours good feed utilizers. This finds its explanation both in the above presented correlations between feed consumption and carcass value and in the very high correlation between growth and feed consumption, which also in the present material was 0.97 .

\section{Discussion}

A very small material was availeble for the present investigation and therefore the reliability of the heritability coefficients based on measurements from ultrasonic photographs is doubtful. Nevertheless the inter-litter differences on which the heritability evaluations are based were, with the exception of lean areas, significant in most cases. Indeed, the poorest heritability coefficients were obtained for cross-sectional areas of the lean. This may of course have been due to difficulty in interpretation of the ultrasonic pictures, but it also seems possible that certain interactions disturb the ranking order of the test groups. An attempt will be made to study the subject more fully by analysing the combined materials from the two years, which are in principle similar.

The fat-lean ratio measured from the ultrasonic picture gives a quite good estimate of the carcass fat-lean ratio. In a critical consideration of the correlations it is well to remember that the ultrasonically determined ratio expersses the fat-lean ratio in the cross-sectional area of the back piece, while the ratio obtained from the dissected carcass is calculated from the amounts of fat + hide and lean + bone in the most valuable part of the half-carcass. This difference may to some extent have a lowering effect on the correlation coefficients.

In evaluating the practical value of ultrasonic photography in selection for breeding the present results justify the conclusion that for the estimation of carcass value the information from the live animal on the lean area will usefully supplement the information obtained on fat. Phenotypic selection based solely on fat will undoubtedly reduce the amount of fat most effectively and will indirectly promote growth and feed utilization, but it does not focus sufficient attention on lean meat. The possibility to estimate also the leanness of the live animal has a direct effect on the main objective of breeding, i.e. an increased amount of lean meat in the carcass. The positive correlation between 
the lean content and the test result index warrants one to expect that selection for leanness also favours rapid growth, which is one of the components of the test result index. The ultrasonic photography of boars which currently is in progress at the South Ostrobothnia (Etelä-Pohjanmaa) phenotype testing station will in due time demonstrate whether or not these conclusions are correct.

\section{Summary}

Ten test litters of Finnish Landrace and ten of Yorkshire breed pigs were studied, each litter consisting of two castrates and two gilts. One week before slaughter of the animals ultrasonic photographs were taken at three sites: A, B and C. Photograph B was taken posterior to the last thoracic vertebra, $A$ at $10 \mathrm{~cm}$ anterior to $\mathrm{B}$, and $\mathrm{C}$ at $10 \mathrm{~cm}$ posterior to $\mathrm{B}$. From the cross-sectional pictures were measured the thickness an areas of the lean and of the overlying fat. The fat-lean rations were then calculated from these measurements. The measurements so obtained from live animals were compared with the carcass value determined from the dissected carcass. The comparisons were made between individuals, using within-breed and within-sex correlation coefficients, and between test litters using within-breed correlation coefficients. The heritability coefficients of the ultraxsonic measurements were also estimated on the basis of variation between the test litters.

In the present study it was found that the mean cross-sectional lean area of three ultrasonic photographs has a closer correlation than any one of the three individual areas to the cross-sectional lean area measured from the carcass. The correlation of this mean value with the lean + bone amount of the most valuable part of the half-carcass approached that of the crosssectional area of the lean measured from the carcass. The correlation of the ultrasonic area measurements with the carcass amounts of fat and lean + bone and with the fat-lean ratio calculated from these was closer tahn that of the ultrasonic thickness measurements. The fat-lean ratio calculated from the areas was also slightly better correlated to carcass quality than was the ratio calculated from the thickness measurements. In other respects the fat thickness measurements appeared to be better than the area measurements. Although the measurements of lean correlated to the carcass value of the animal more poorly than the fat measurements, the highest correlations were nevertheless obtained by the combined use of the fat and lean measurements.

\section{Acknowledgements}

We are grateful to Mr. J. Partanen, Director of the Pig Husbandry Experiment Station, and to the other staff members and personnel of the experimet station for the assistance rendered by them, which made it possible for us to carry out this investigation. 


\section{REFERENCES}

Andersen, B. B., Pedersen, O. K., Busk, H., Lund, S. A. \& Jensen, P. 1970 . Ultraschallmessungen bei Rinder und Schwein. Sonderdruck aus Die Fleischwirtschaft. 50,6.

Anderson, L. M. \& WAhlströM, R. C. 1969. Ultrasonic Prediction of Swine Carcass Composition. J. Anim. Sci. 28: 593-600.

Aulstad, D. 1969. In Vivo Estimation of Carcass Composition in Young Boars. II The Use of Ultrasonic Measurements of Backfat Thickness. Acta Agr. Scand. 19: 189-196.

BLENDL, H. M. 1968. Eigenleistungsprüfung im Feld mittels Echolotverfahren beim Schweinin Bayern. Z-kunde 40: 264-283.

Busk, H. \& Pedersen, O. K. 1972. Mâlning af arealet af m. longissimus dorsi og sidespæktykkelse på levende svin ved hjælp af scanningsapparat. Særtryk af Forsøgslabora toriets årbog 1972: 102-107.

EttalA, E. 1973. Boars for breeding: a study of methods of evaluation used at testing stations. J. Sci. Agr. Soc. Fin. 45, 1:17-119.

GLODEK, P. 1964. Ùber ein unter praktischen Verhältnissen anwendbares Verfahren zur Abschätzung des Fleischbildungsvermögens lebender Schweine mit Ultraschall. Zkunde 36: 365-370.

Halkonen, M.-L. 1970. Elävän sian teuraslaadun arvioiminen. B.Sc.-thesis. University of Helsinki, Department of Animal Breeding.

Hazel, L. N. \& Kline, E. A. 1959. Ultrasonic Measurement of Fatness in Swine. J. Anim. Sci. 18: $815-819$.

Hofmann, F. \& Peter, W. 1964. Die Anwendungsmöglichkeiten der Speckdickenmessung mit Ultraschall bei der Selektion in der Fleischschweinezucht. Arch. Tierzucht 7: 255 - 287.

Horst, P. 1971. Ultrasonic and X-Ray Measuring Techniques in Pig Performance Tests. I The Ultrasonic Technique. Z. Tierz. Zücht. biol. 88: 89-98.

- - 1971. Erste Untersuchungsergebnisse über den Einsatz des "Vidoson»-Schnittbildgerätes beim Schwein. Z-kunde 43: 208-218.

Langlet, J. F., Ernst, E. \& Glaner, H. D. 1968. Die Möglichkeit einer Selektion beim Schweinen mit Hilfe von Echolotmessungen unter den Verhältnissen der Praxis. Z. Tierz. Zücht. biol. $85: 27-35$.

LAUPRECHT, E. 1960. Bericht über Ergebnisse von Messungen mit dem Ultraschall-Echolot an Schweinen. Z-kunde 32: 441-449.

- - Kirsch, W., Rittler, A., Munzer, W. \& Fewson, D. 1965. Untersuchungen über die Abschätzung des Anteiles der fleisch- und fettreichen Teilstücke aufgrund von Echolotmessungen am lebenden Schwein. Z. Tierz. Zücht. biol. 81: 89-99.

- - Schutzbar, W. von \& Flock, D. 1967. Untersuchungen über die Heritabilität der mit dem Ultraschall-Echolot an Jungebern ermittelten Speck- und Muskeltiefe. Z. Tierz. Zücht. biol. 84: 80-95.

- - Walter, E. \& SaAthoff, F. 1960. Beitrag zur Messung der Querschnittsfläche des langen Rückenmuskels (musculus longissimus dorsi) und der darüberliegenden Fettschicht von lebenden Schweinen mit dem Ultraschall-Echolot. Z-kunde 32: 450-464.

Price, J. F., Pearson, A. M. \& Emerson, J. A. 1960. Measurement of the Cross-sectional Area of the Loin Eye Muscle in Live Swine by Ultrasonic Reflections. J. Anim. Sci. 19: 786-789.

Ritrter, A. 1967. Echolotmessungen als Hilfsmittel für die Zuchtwertschätzung beim Schwein. 2. Mitteilung: Weitere Untersuchungen über die genetische Fundierung der Echolotmessungen an Jungebern. Z. Tierz. Zücht. biol. 84: 179-187.

- -1968 . Echolotmessungen als Hilfsmittel für die Zuchtwertschätzung beim Schwein. 3. Mitteilung: Abschätzung des Fleisch- und Fettanteiles auf Grund von Echolotmessungen am lebenden Schwein. Z. Tierz. Zücht. biol. 85: 78-89.

SchoEN, P. 1964. Untersuchungen über die Eignung von Echolotmessungen am lebenden Schwein zur Abschätzung des Anteiles der fleisch- und fettreichen Teilstücke. Z-kunde 36: $206-216$.

Schutzbar, W. von \& Werhahn, E. 1972. Beitrag zur Schätzung des Anteils wertvoller Teilstücke am Schlachtkörper mit Hilfe von Messungen mit dem Ultraschall-Echolot am Rücken unde am Schinken lebender Schweine. Z-kunde 44: 323-330. 
Stouffer, J. R., 1965. Objective technical methods for determining carcass value in live animals with special emphasis on ultrasonics. E. A. A. P., Nordwijk.

- - Wallentine, M. V., Wellington, G. H. \& Diekmann, A. 1961. Development and Application of Ultrasonic Methods for Measuring Fat Thickness and Rib-Eye-Area in Cattle and Hogs. J. Anim. Sci. 20: 759-767.

Uusisalmi, U. 1969. Vorläufige Ergebnisse über das Messen der Schlachteigenschaften beim Schwein. J. Sci. Agr. Soc. Fin. 41: 50-59.

Werhahn, E. 1968. Untersuchungen über die Eignung verschiedener Echolotmessverfahren zur Abschätzung des Fleisch- und Fettanteiles in Schlachtkörper von Schweinen. Z. Tierz. Zücht. biol. 85: 135-142.

VARo, M. 1967. Preliminary results of the sfield testing of A. I. boars. Acta Agr. Fenn. 109, 1: $105-109$.

— - 1971. Sikojen ultraäänikuvauksen tuloksia. Sika 2: 5-7.

\title{
SELOSTUS
}

\section{Kokemuksia elävien sikojen teuraslaadun määrittämisestä ultraäänikuvauksella.}

\author{
Mrkko Varo, Marjatta Perälä, Matri Ojala ja Hannu Varo \\ Kotieläinten jalostustieteen laitos, Helsingin Yliopisto, 00710 Helsinki.
}

Tutkimuksen aineistona oli 10 maatiaisrodun ja 10 yorkshirerodun kahdesta leikko- ja kahdesta emakkoporsaasta muodostettua kantakoeryhmää. Eläimet kuvattiin viikkoa ennen teurastusta kolmesta kohdasta: A, B ja C. B-kuva otettiin viimeisen rintanikaman takaa, A-kuva $10 \mathrm{~cm}$ tämån kohdan etu- ja C-kuva takapuolelta. Saaduista kyljysselän poikkileikkauskuvista mitattiin kyljyslihaksen ja sen päällä olevan silavan paksuudet ja pinta-alat. Näistä mitoista laskettiin edelleen silava/liha-suhteet. Elävistä eläimistä näin saatuja mittoja verrattiin ruhojen leikkelyssä todettuun teurasarvoon. Vertailut tehtiin yksilöittäin rotujen ja sukupuolen sisäisin ja koeryhmittäin rotujen sisäisin korrelaatiokertoimin. Myös ultraäänimittojen heritabiliteettikertoimet arvioitiin koeryhmien välisen muuntelun perusteella.

Tässä tutkimuksessa ilmeni, että kolmeen ultraänikuvaan perustuva kyljyslihaksen poikkileikkauspinta-alojen keskiarvo oli korreloinut ruhosta todettuun kyljyslihaksen poikkileikkauspinta-alaan kiinteämmin kuin yksikään pinta-ala erikseen. Tämän keskiarvon yhteys ruhon puolikkaan arvokkaimman osan liha + luumäärään oli lähes yhtä hyvä kuin ruhosta todetun kyljyslihaksen poikkileikkauspinta-alan. Pinta-alamittojen yhteys leikkelyssä todettuun silavan ja lihan + luun määrään sekä näistä laskettuun silava/liha-suhteeseen oli kiinteämpi kuin paksuusmittojen. Myös pinta-aloista laskettu silava/liha-suhde oli hieman voimakkaammassa korrelaatiossa ruhon laatuun kuin paksuusmitoista laskettu suhde. Muuten näyttivät silavan paksuusmitat pinta-alamittoja paremmilta. Vaikka lihasmitat korreloituivat ruhon teurasarvoon huonommin kuin silavan mitat, saatiin kuitenkin suurimmat korrelaatiot silava- ja lihasmittojen yhteiskäytöllä. 
Appendix A. Some correlation coefficients between amount of lean + bone in cut carcass and ultrasonic and carcass measurements.

\begin{tabular}{|c|c|c|c|c|}
\hline Characteristic & $\mathrm{n}$ & $\begin{array}{l}\text { Ultrasonic } \\
\text { measurements }\end{array}$ & $\begin{array}{c}\text { Carcass } \\
\text { measurements }\end{array}$ & Author \\
\hline \multirow{2}{*}{\multicolumn{5}{|c|}{$\begin{array}{l}\text { Lean }+ \text { bone in carcass } \\
\quad-\text { fat thickness }\end{array}$}} \\
\hline & 54 & $-0.52--0.73$ & $-0.53--0.74$ & Aulstad $(1969)^{4}$ \\
\hline & 108 & $-0.12--0.43$ & $-0.13--0.55$ & BLENDL $(1968)^{3}$ \\
\hline & 285 & $-0.20--0.26$ & $-0.35--0.48$ & ETtALA $(1973)^{2}$ \\
\hline & 205 & $-0.42--0.56$ & $-0.38--0.60$ & GeRWIG (1965 a) \\
\hline & 191 & $-0.42--0.71$ & $-0.49--0.60$ & HALKONEN $(1970)^{2}$ \\
\hline & 56 & $-0.76--0.90$ & -0.85 & HAzel \& KLINE $(1959)^{2}$ \\
\hline & 132 & -0.27 & -0.31 & LAUPRECHT et al. $(1965)^{2}$ \\
\hline & 101 & $-0.23--0.37$ & $-0.35--0.54$ & MENNERICH (1967) \\
\hline & 1332 & $-0.61--0.63$ & $-0.46--0.50$ & RITTLER $(1968)^{2}$ \\
\hline & 1332 & $-0.83--0.86^{1}$ & $-0.65--0.74^{1}$ & $\rightarrow$ \\
\hline & 100 & $-0.65--0.69$ & $-0.49--0.68$ & SCHOEN $(1964)^{2}$ \\
\hline & 190 & $-0.15--0.43$ & $-0.20--0.48$ & SUNDGREN (1969) \\
\hline & 190 & $-0.55--0.57$ & $-0.43--0.49$ & 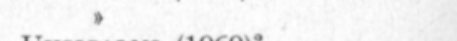 \\
\hline & 97 & $-0.18--0.41$ & $-0.31--0.46$ & UUSISALMI $(1969)^{2}$ \\
\hline & 126 & $-0.58--0.76$ & $-0.68--0.70$ & WERHAHN $(1968)^{3}$ \\
\hline \multirow[t]{4}{*}{ - fat area } & 134 & $-0.51--0.63$ & $-0.39--0.55$ & BLENDL $(1968)^{3}$ \\
\hline & 111 & $-0.19--0.36$ & $-0.33--0.35$ & Horst $(1971)^{2}$ \\
\hline & 100 & -0.49 & -0.52 & SCHOEN $(1964)^{2}$ \\
\hline & 126 & -0.68 & -0.64 & WERHAHN $(1968)^{3}$ \\
\hline \multirow[t]{5}{*}{ - lean thickness } & 132 & $0.36-0.42$ & - & LAUPRECHT et al. $(1965)^{2}$ \\
\hline & 1332 & $0.31-0.35$ & - & RITTLER $(1968)^{2}$ \\
\hline & 1332 & $0.55-0.57^{1}$ & $\begin{array}{l}0.61^{1} \\
0.16\end{array}$ & \\
\hline & 100 & 0.12 & 0.16 & SCHOEN $(1964)^{2}$ \\
\hline & 126 & 0.34 & - & WERHAHN $(1968)^{3}$ \\
\hline \multirow[t]{8}{*}{ - lean area } & 78 & $0.50-0.53$ & $0.57-0.60$ & ANDERSON \& WAHLSTROM $(1969)^{2}$ \\
\hline & $\begin{array}{l}134 \\
102\end{array}$ & $\underset{0.41}{0.46-} 0.66$ & $\begin{array}{c}0.56- \\
-\end{array}$ & $\begin{array}{l}\text { BLENDL }(1968)^{3} \\
\text { DICKMANN }(1960)\end{array}$ \\
\hline & 111 & $0.17-0.42$ & $0.50-$ & $\begin{array}{l}\text { DICKMANN }(1960) \\
\text { HoRST }(1971)^{2}\end{array}$ \\
\hline & 132 & $0.36-0.42$ & 0.66 & LAUPRECHT et al. $(1965)^{2}$ \\
\hline & 101 & 0.16 & 0.69 & MENNERICH (1967) \\
\hline & 91 & 0.53 & - & Pfeiffer (1970) \\
\hline & 100 & 0.32 & 0.52 & SCHOEN $(1964)^{2}$ \\
\hline & 126 & 0.46 & 0.70 & WERHAHN $(1968)^{3}$ \\
\hline \multirow[t]{4}{*}{ - fat-lean ratio of thicknesses } & 132 & $-0.55--0.59$ & - & LAUPRECHT et al. $(1965)^{2}$ \\
\hline & $\begin{array}{l}1332 \\
1332\end{array}$ & $\begin{array}{l}-0.59--0.62 \\
-0.81--0.90^{1}\end{array}$ & - & RITTLER $(1968)^{2}$ \\
\hline & 100 & $-0.81-0.65$ & -0.75 & SCHOEN $(1964)^{2}$ \\
\hline & 126 & -0.73 & - & WERHAHN $(1968)^{3}$ \\
\hline \multirow[t]{3}{*}{ - fat-lean ratio of areas } & 111 & $-0.40--0.49$ & $-0.53--0.55$ & Horst $(1971)^{2}$ \\
\hline & 100 & -0.65 & -0.73 & SCHOEN $(1964)^{2}$ \\
\hline & 126 & -0.70 & -0.80 & WERHAHN $(1968)^{3}$ \\
\hline \multirow[t]{3}{*}{ - Multiple correlation; } & 132 & 0.59 & - & LAUPRECHT et al. $(1965)^{2}$ \\
\hline & 132 & $0.56-0.58$ & - & \\
\hline & $\begin{array}{l}132 \\
105\end{array}$ & $\begin{array}{l}0.60 \\
0.72\end{array}$ & $\overline{-}$ & SCHUTZBAR \& WERHAHN $(1972)^{2}$ \\
\hline
\end{tabular}

$1=$ Genetic correlation

$2=$ Lean + bone of most valuable part of carcass

$3=$ Lean + bone of half carcass

$4=$ Lean + bone of whole carcass
Multiple correlations;

a, 3 fat thickness measurements

b, 2 fat and 1 lean thickness measurements

c, 4 fat and 1 lean thickness measurements

d, 2 fat and 2 lean thickness measurements 
ppendix B. Some correlation coefficients between amount of fat in cut carcass and ultrasonic and carcass easurements.

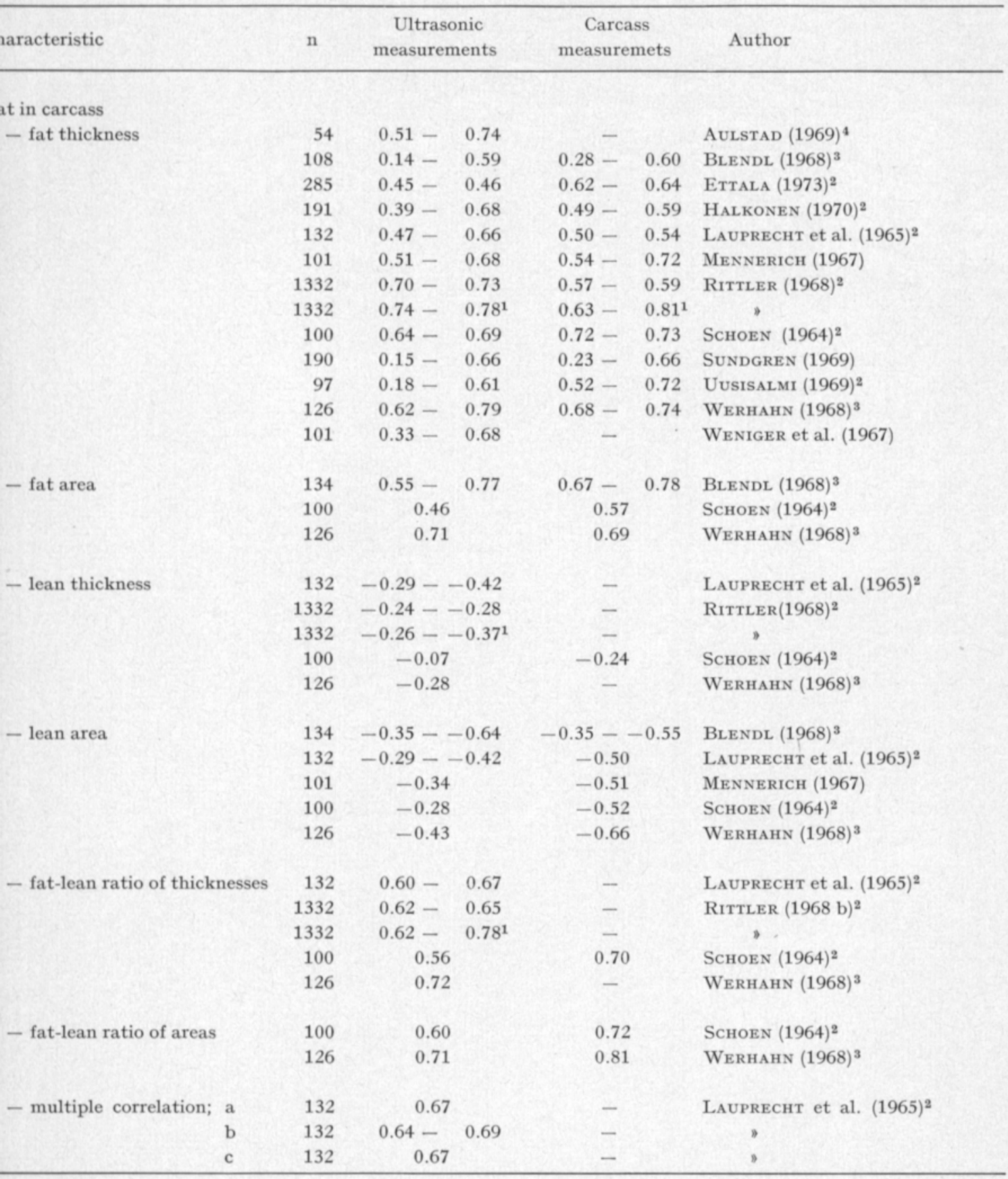

$=$ Genetic correlation

$=$ Fat of most valuable part of carcass

$=$ Fat of half carcass

$=$ Fat of whole carcass
Multiple correlations;

a, 3 fat thickness measurements

b, 2 fat and 1 lean thickness measurements

c, 4 fat and 1 lean thickness measurements 
Appendix C. Some correlation coefficients between fat-lean ratio in cut carcass and ultrasonic and carca measurements.

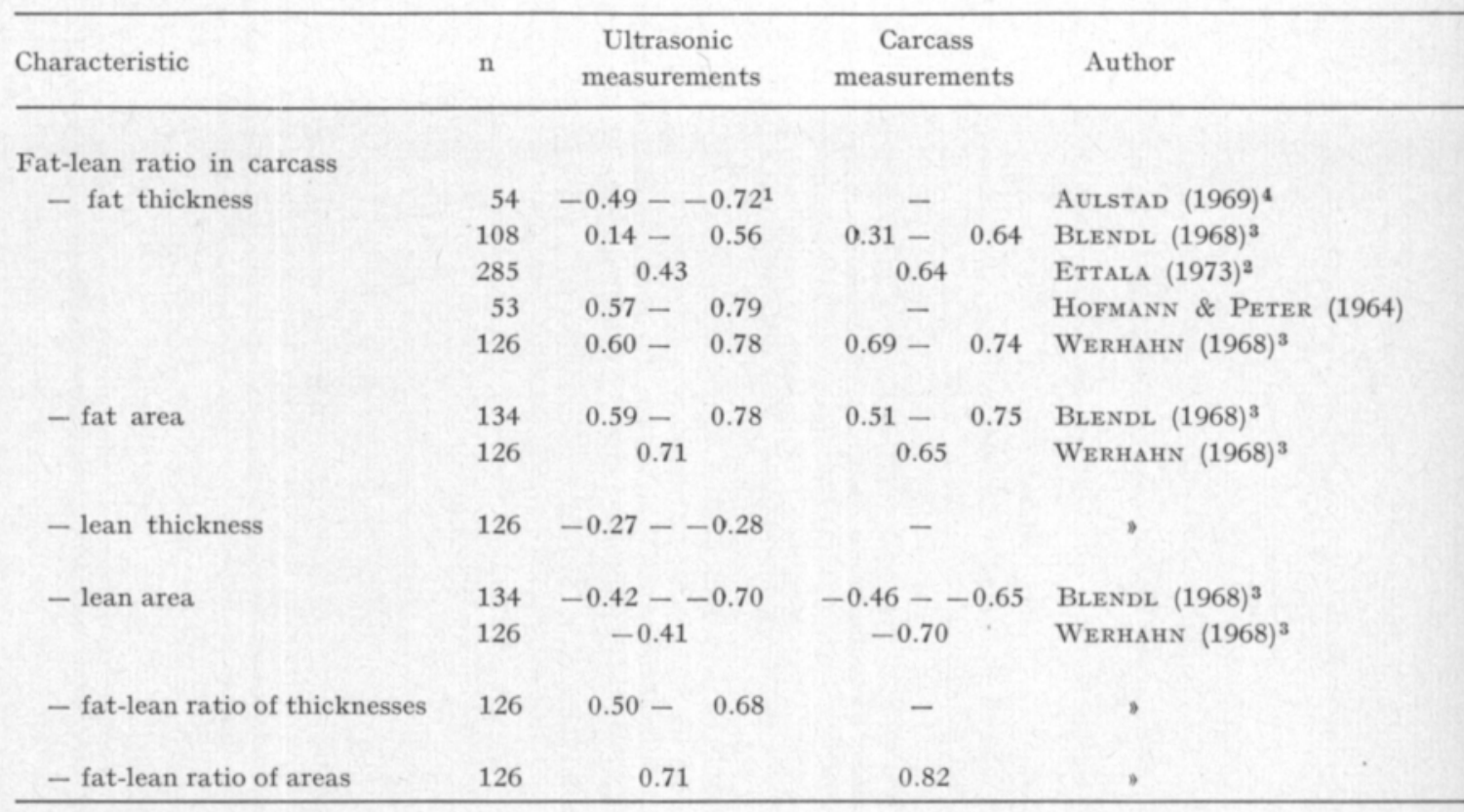

$1=$ Lean-fat ratio in carcass

$2=$ Fat-lean ratio of most valuable part of carcass

$3=$ Fat-lean ratio of half-carcass

$4=$ Fat-lean ratio of whole carcass 